\title{
A $\beta$-Dependent Inhibition of LTP in Different Intracortical Circuits of the Visual Cortex: The Role of RAGE
}

\author{
Nicola Origliaa ${ }^{a}$, Simona Capsoni ${ }^{b}$, Antonino Cattaneo $^{b, c}$, Fang Fang $^{d}$, Ottavio Arancio ${ }^{d}$, Shi \\ Du Yan ${ }^{\mathrm{d}, *}$, and Luciano Domenicia,e, \\ Institute of Neuroscience (CNR), Pisa, Italy \\ bEuropean Brain Research Institute, Roma, Italy \\ 'International School for Advanced Studies (SISSA), Trieste, Italy \\ dDepartment of Pathology and Surgery \& Taub Institute, Columbia University, New York, NY, \\ USA \\ eDepartment STB, University of L'Aquila, L'Aquila, Italy
}

\begin{abstract}
Oligomeric amyloid- $\beta$ (A $\beta$ ) interferes with long term potentiation (LTP) and cognitive processes, suggesting that $A \beta$ peptides may play a role in the neuronal dysfunction which characterizes the early stages of Alzheimer's disease (AD). Multiple lines of evidence have highlighted RAGE (receptor for advanced glycation end-products) as a receptor involved in $\mathrm{A} \beta$-induced neuronal and synaptic dysfunction. In the present study, we investigated the effect of oligomeric soluble $A \beta_{1-42}$ on LTP elicited by the stimulation of different intracortical pathways in the mouse visual cortex. A variety of nanomolar concentrations $(20-200 \mathrm{nM})$ of $A \beta_{1-42}$ were able to inhibit LTP in cortical layer II-III induced by either white matter (WM-Layer II/III) or the layer II/III (horizontal pathway) stimulation, whereas the inhibition of LTP was more susceptible to $A \beta_{1-42}$, which occurred at $20 \mathrm{nM}$ of $\mathrm{A} \beta$, when stimulating layer II-III horizontal pathway. Remarkably, cortical slices were resistant to nanomolar $A \beta_{1-42}$ in the absence of RAGE (genetic deletion of RAGE) or blocking RAGE by RAGE antibody. These results indicate that nanomolar A $\beta$ inhibits LTP expression in different neocortical circuits. Crucially, it is demonstrated that $A \beta$-induced reduction of LTP in different cortical pathways is mediated by RAGE.
\end{abstract}

\section{Keywords}

Alzheimer's disease; amyloid- $\beta$; neocortical areas; RAGE; synaptic plasticity

\section{INTRODUCTION}

Extensive deposition of amyloid- $\beta$ (A $\beta$ ) leading to the formation of plaques is considered one of the key pathological features of Alzheimer's disease (AD) [1]. A $\beta$ derives from the cleavage of amyloid- $\beta$ protein precursor and exists in a variety of forms including monomers, oligomers, protofibrils, and fibrils [2].

\footnotetext{
(C) 2009 - IOS Press and the authors. All rights reserved

"Corresponding authors: Luciano Domenici, Institute of Neuroscience (C.N.R.), Via G. Moruzzi 1, 56100, Pisa, Italy. Tel.: +39 50 3153182; Fax: +39 50 3153220; domenici@in.cnr.it. Shi Du Yan, Department of Pathology and Surgery, Taub Institute, Columbia University, New York, NY10032, USA. Tel.: +1 212342 1304; Fax: +1 212305 5337; sdy1@ @olumbia.edu.
} 
Previous studies have shown that soluble oligomeric $A \beta_{1-42}$, including the human naturally secreted peptide, acutely inhibits long-term potentiation (LTP) in the hippocampus [35],one of the main forms of synaptic plasticity that is thought to underlie learning and memory [6]. These results are in agreement with recent observations in both AD patients and AD-type mouse models showing that impairment of memory and synaptic deficit occur prior to extensive extracellular deposition of $A \beta$ in the brain [7-12]. Oligomeric $A \beta$ plays a key pathogenic role in neuronal and synaptic dysfunction, which is associated with the early phase of AD progression [13]. Our recent study [14] further supports the concept that oligomeric $A \beta$ is able to disrupt LTP induction in the entorhinal cortex,an area intimately connected to the hippocampus which is involved in learning and memory. Furthermore, histopathological studies have demonstrated that the hippocampus and the parahippocampal formation are the earliest affected regions during $\mathrm{AD}$, suggesting a precise chronological (and hierarchical) order of involvement: from limbic to associative and from associative to primary cortical areas including the visual cortical areas $[15,16]$. However, recent studies have highlighted an apparent dichotomy between the progress of histopathological findings in different brain areas and the occurrence of visual dysfunctions in $\mathrm{AD}$ patients. In particular, clinical studies support a link between cognitive performance and visual dysfunction even at an early stage of AD. Impairment of higher order visual processing, such as the loss of color discrimination, stereoacuity, contrast sensitivity, and backward masking, have been frequently described in AD patients [17-19]. The gradual loss of memory and attention are also frequently accompanied by alteration of visuospatial function in animal models and AD patients [20,21]. Finally, the cholinergic deficit associated with cognitive impairment represents an early event in the visual cortex of AD patients [22]. These observations imply an impact of visual synaptic dysfunction on the pathogenesis of $\mathrm{AD}$ but the mechanism by which visual synaptic function is linked to $\mathrm{A} \beta$ remains unclear.

RAGE (receptor for advanced glycation end-products) is a multiligand receptor of the immunoglobulin superfamily that functions as a cell surface binding site for $A \beta$ [23]. Importantly, RAGE possesses high affinity binding to oligomeric $A \beta$ [24]. Growing evidence highlights RAGE as a factor that mediates and amplifies the effects of $A \beta$ on neuronal target cells, some of which are reported in detail: i) enhanced expression of RAGE in $A \beta$ enriched environments [25-27]; ii) expression of RAGE on cells critical for neurodegenerative pathology (neurons, glia, endothelial cells, pericytes of the blood brain barrier cells,microglia) $[28,29]$; and iii) RAGE binds cytokine-like mediators exerting proinflammatory activity [30]. Our recent studies provide substantial evidence that A $\beta$ induced suppression of LTP in hippocampus [7] and entorhinal cortex [14] is mediated by RAGE.

In the present study, we extended our previous findings on the entorhinal cortex by investigating whether: i) oligomeric $\mathrm{A} \beta_{1-42}$ inhibits LTP in occipital visual cortex; ii) LTP elicited by stimulation of different intracortical connections is sensitive to different concentrations of $A \beta_{1-42}$; and iii) there is a role for RAGE in $A \beta$-mediated synaptic function in occipital visual cortex. We examined the effects of oligomeric $A \beta_{1-42}$ at a variety of nanomolar concentrations $(2-200 \mathrm{nM})$ on basic synaptic transmission and expression of LTP and determined the effects of RAGE abrogation on A $\beta$-induced synaptic function in occipital visual cortex lacking RAGE or in which endogenous RAGE was blocked by a specific RAGE antibody.

\section{MATERIALS AND METHODS}

Procedures followed in experimental animal subjects were done in accordance with the guidelines approved by European Community Council Directive and Italian Ministry of Health (129/2000-A, December 13, 2000). 


\section{Homozygous RAGE null mice}

Homozygous RAGE-null mice were generated and characterized as described previously [31,32]. Homozygous RAGE null mice were backcrossed for more than 10 generations into C57BL/6 mice before study. Male RAGE null and littermate control mice were used.

\section{Pharmacological agents and MALDI-MS analysis}

Solutions containing synthetic $A \beta_{1-42}$ or the reverse peptide ( $\left.{ }_{42-1}\right)$ (Biosource, Ca, USA) were prepared following methods previously described [14,33, 34]. Briefly, the lyophilized peptide was suspended in 100\% 1,1,1,3,3,3-hexafluoro-2-propanol (HFIP; Sigma-Aldrich), and HFIP was allowed to evaporate. The resulting peptide films were stored at $-20^{\circ} \mathrm{C}$. Twenty-four hours prior to use, the aliquots were added to DMSO (Sigma-Aldrich, MO, USA) and sonicated for 10 minutes. Oligomeric $A \beta_{1-42}$ was obtained by diluting an aliquot of $\mathrm{A} \beta_{1-42} / \mathrm{DMSO}$ solution with a small volume of normal recording bath solution (ACSF solution, see slice preparation), vortexing for 30 seconds, and then incubating at $4{ }^{\circ} \mathrm{C}$ for 16 hours. Before using, oligomeric $A \beta$ was added to ACSF to obtain final concentrations in the nanomolar range. This synthetic $A \beta$ has been characterized both biochemically and electrophysiologically, showing similar biological effects at low nanomolar concentrations as naturally secreted oligomers of $A \beta$ [35]. Oligomeric composition of $A \beta_{1-42}$ solutions was characterized by using mass spectrometry. Briefly, protein samples were analyzed using the modified thin-layer method of Cadene and Chait [36]. The matrix used was a saturated solution of a-cyano-4-hydroxycinnamic acid in 3:1:2 (v/v/v/) formic acid/ water/ isopropanol. The protein solution was mixed 1:5 with matrix solution and spotted on the sample plate prepared with a thin layer of a-cyano-4-hydroxycinnamic acid and allowed to dry. Standard solutions of $6 \mathrm{mM}$ apomyoglobin and $15 \mathrm{mM}$ bovine serum albumin were mixed with matrix and spotted in the same way for use as calibrants. Spectra were acquired on a Voyager-DE Pro (Applied Biosystems, Foster City, CA) operating in linear mode. Instrument settings were as follows: accelerating voltage, $25000 \mathrm{~V}$; grid voltage, $93 \%$; extraction delay time, $1050 \mathrm{~ns}$; laser intensity 2200-2700.

Specific antibodies to RAGE were described in previous studies [23] and purified rabbit non-immune IgG were used as control (Bethyl, TX, USA).

\section{Slice preparation}

Animals were deeply anesthetized by urethane ( $20 \%$ solution, $0.1 \mathrm{ml} / 100 \mathrm{~g}$ b.w.) via intraperitoneal injection and then decapitated after tail pinch reflex disappearance. The brain was rapidly removed and $400 \mu \mathrm{m}$ thick coronal sections of the occipital pole were sliced by a vibratome. All steps were performed in ice cold ACSF solution (in $\mathrm{mM}: \mathrm{NaCl}, 119 ; \mathrm{KCl}$, $2.5 ; \mathrm{CaCl}_{2}, 2 ; \mathrm{MgSO}_{4}, 1.2 ; \mathrm{NaH}_{2} \mathrm{PO}_{4}, 1 ; \mathrm{NaHCO}_{3}, 26.2 ;$ glucose, 11 ) bubbled with $95 \%$ $\mathrm{O}_{2} / 5 \% \mathrm{CO}_{2}$. Prior to recording, slices were stored for at least 1 hour in a recovery chamber containing oxygenated ACSF solution at room temperature. During electrophysiological recordings, the slices were perfused at $2.5-3 \mathrm{ml} / \mathrm{min}$ with oxygenated ACSF, at $33 \pm 1{ }^{\circ} \mathrm{C}$.

\section{Electrophysiological recordings}

Extracellular field potentials (FPs) were evoked in visual cortex slices via a tungsten concentric bipolar stimulating electrode placed at the white matter (WM)/ layer VI border to stimulate vertical intracortical pathway (Fig. 1A) or in layer II/III to stimulate horizontal intracortical pathway (Fig. 1B), while the recording electrode (pulled glass capillaries, OD. $1.0 \mathrm{~mm}$-ID $0.78 \mathrm{~mm}$ ) was placed in layer II/III (Fig. 1A, B). The amplitude of the FPs was used as a measure of the evoked population excitatory current [37,38]. Baseline responses were obtained with a stimulation intensity that yielded 50-60\% of maximal amplitude. All FPs had peak latency between 4.5 to $6 \mathrm{~ms}$. FP amplitude was monitored every 20 seconds 
and averaged every three responses by an online data acquisition software [39]. After 15 minutes of stable baseline, recording high frequency stimulation (HFS, three trains of 100 pulses at $100 \mathrm{~Hz}, 10$ second interval) was used to induce LTP. LTP magnitude was measured as the average of FP amplitudes between the 40th and the 50th min after HFS. Values were expressed as mean \pm SEM percentage change relative to their mean baseline amplitude.

A $\beta$ peptides were applied through general perfusion for 10 minutes starting from 5 minutes before HFS.

\section{Statistical analysis}

Statistical comparisons were performed by applying two-way ANOVA for repeated measures followedby all pair-wise multiple comparison test. Differences were considered significant when $p<0.05$.

\section{RESULTS}

\section{A brief application of oligomeric $A \beta_{1-42}$ affects LTP in cortical layer II/III}

We used synthetic $A \beta_{1-42}$ at nanomolar concentration ranges, i.e., at concentrations lower than those used for neurotoxicity and cell death [14]. Before application, we characterized the oligomeric composition of synthetic $A \beta_{1-42}$ by mass spectrometry analysis. There were monomers, dimers, and trimers in the $A \beta$ preparation (Fig. 2).

LTP was reliably elicited by high frequency stimulation (HFS) of the white matter in mouse slices containing visual cortical areas (Fig. 3A) in agreement with the previous reports $[37,38,40]$. The amount of LTP 50 minutes after HFS was $139 \pm 2 \%$ of baseline $(n=18$ slices, 8 mice; Fig. 3A). Bath application for 10 minutes of $200 \mathrm{nM} \mathrm{A} \beta_{1-42}$ or the reverse control peptide $(42-1,200 \mathrm{nM})$ did not result in a significant change of FP amplitudes during baseline recording (Fig. 3C), or modification of input/output curves (data not shown), similarly to those reported in entorhinal cortex slices [14]. These results suggest that $A \beta_{1-42}$ in the nanomolar range does not affect basal synaptic transmission. When $200 \mathrm{nM} \mathrm{A} \beta_{1-42}$ was bath-applied for 10 minutes starting 5 minutes before HFS delivery in interleaved experiments, it was able to completely inhibit LTP expression $(94 \pm 9 \%, n=9,6$ mice; $p<$ 0.05 vs. vehicle treated slices; Fig. 3B). A lower concentration of $\mathrm{A} \beta(20 \mathrm{nM})$, did not affect LTP in layer II/III for the stimulation of WM $(132 \pm 9 \%, n=6,3$ mice; Fig. 2B). LTP amplitude was unaffected in slices treated with the reverse peptide $A \beta_{42-1}(200 \mathrm{nM})(132 \pm$ $10 \%, n=6,3$ mice; Fig. 3D).

To investigate whether the vulnerability of LTP to $A \beta_{1-42}$ is input specific, we applied $A \beta_{1-42}$ while LTP was induced by the stimulation of a different synaptic pathway in the occipital cortex. The recording electrode was placed in layer II/III as usual, while the stimulating electrode was placed in the same layer II//III, laterally to the recording electrode, to stimulate horizontal intracortical connections [37]. In control vehicle treated slices ( $n=8$, 4 mice), the mean LTP elicited by HFS of the horizontal layer II/III pathway was $145 \pm 7 \%$, (Fig. 4A). LTP was completely inhibited by bath perfusion of $200 \mathrm{nM} \mathrm{A} \beta_{1-42}(105 \pm 4 \%, n$ $=7,4$ mice, Fig. 4B). In contrast to the observation for the stimulation of the WM layer II/ III vertical pathway, $20 \mathrm{nM} \mathrm{A} \beta_{1-42}$ was sufficient to block LTP elicited by the stimulation of the horizontal layer II/III pathway (108 $\pm 1 \%, n=6,3$ mice vs. $145 \pm 7 \%, n=8$ in vehicle treated slices, $p<0.05$; Fig. 4B). Slices treated with $2 \mathrm{nM} \mathrm{A} \beta_{1-42}$ had a normal LTP (138 \pm $5 \%, n=9,4$ mice; Fig. 4B). Thus, LTP sensitivity to $\mathrm{A} \beta_{1-42}$ concentrations shifts towards lower values when stimulating the horizontal connections in layer II/III in comparison with the stimulation of the vertical connections from WM to layer II/III. These results indicate 
that the horizontal connection in layer II/III of neocortex is highly susceptible to A $\beta$-induced synaptic insults.

\section{RAGE deficiency rescues $A \beta_{1-42}$-induced inhibition of LTP in cortical layer II/III}

Previous studies showed that RAGE mediates $A \beta$ induced synaptic plasticity impairment in the hippocampus [7] and entorhinal cortex [14]. To test whether RAGE was involved in $A \beta_{1-42}$-dependent impairment of LTP in neocortical areas, we examined the effect of a brief application of $A \beta_{1-42}$ on LTP expressed in occipital slices from RAGE null mice or slices pretreated with anti-RAGE IgG The basic FP features (amplitude, latency, waveshape, input/output curves) did not differ between RAGE null and age-matched WT mice (data not shown), in agreement with the findings reported in entorhinal cortex slices [14]. Moreover, a deficiency of RAGE (RAGE null mice) and a blockade of RAGE by specific antibodies to RAGE (slices incubated with anti-RAGE IgG, $2.5 \mu \mathrm{g} / \mathrm{ml}$ for at least 2 hours prior to recordings) did not affect LTP expression (Fig. 5A). LTP elicited by the stimulation of WM-layer II-III vertical pathway was $148 \pm 5 \%(n=8,4$ mice, $p>0.05$ vs. control vehicle slices) in RAGE null mice and $145 \pm 6 \%$ in slices pre-treated with anti-RAGE IgG ( $n=6,3$ mice; $p>0.05$ vs. control vehicle slices). Similarly, the absence of RAGE did not affect the magnitude of LTP elicited by the stimulation of the horizontal pathway in layer IIIII ( $138 \pm 4 \%$ in RAGE null slices $n=9,4$ mice; $p>0.05$ vs. control slices, Fig. 5C). These results indicate that RAGE deficiency or blockade of RAGE by specific antibody to RAGE does not interfere with normal synaptic function. However, abrogation of RAGE rescued the reduction of LTP induced by $A \beta$. When $A \beta_{1-42}(200 \mathrm{nM})$ was bath-applied in slices from RAGE null mice or slices pre-treated with anti-RAGE IgG, the LTP elicited by stimulation of WM-layer II-III pathway was normal (Fig. 5B). The LTP amplitude in RAGE null (145 \pm $11 \%, n=8,4$ mice) and anti-RAGE IgG-incubated ( $142 \pm 12 \%, \mathrm{n}=6,3$ mice) slices treated with $\mathrm{A} \beta$ was significantly increased $(p<0.05)$ with respect to LTP in slices treated with A $\beta$ alone while the values were similar when compared with those obtained in RAGE null or anti-RAGE IgG slices without A $\beta$. Similarly, the absence or blockade of RAGE was able to re-establish a normal LTP elicited by stimulation of layer II-III horizontal pathway in A $\beta$ treated slices (RAGE null plus $\mathrm{A} \beta=144 \pm 14, n=9,5$ mice; Fig. $5 \mathrm{D} ; p<0.05$ vs. vehicle plus $A \beta$ ). Thus, the absence of RAGE or its functional blockade makes cortical LTP resistant to nanomolar concentrations of $A \beta_{1-42}$.

\section{DISCUSSION}

Our results confirm and extend previous observations in the parahippocampal area, the entorhinal cortex, indicating that non-toxic oligomeric $A \beta_{1-42}$ affects LTP through RAGE activation. In particular, we report here that: i) A $\beta$-RAGE signaling is involved in LTP alteration in a neocortical area, the visual cortex; and ii) $A \beta_{1-42}$ at concentrations of 20 and $200 \mathrm{nM}$ differently affects the LTP elicited by stimulation of two different intracortical pathways in the visual cortex.

Oligomeric forms of $\mathrm{A} \beta$ play a critical role in the pathogenesis of $\mathrm{AD}$. $\mathrm{A} \beta$ contributes to the early impairment of cognitive functions such as learning and memory $[41,42]$. The early signs of functional impairment precede the extensive neurodegeneration with a significant accumulation of $\mathrm{A} \beta$ in brain during a middle/late phase of $\mathrm{AD}$. The basic mechanism of this functional impairment is thought to involve perturbation of synaptic efficiency in different brain areas, and to be strictly associated with an increased extracellular level of $A \beta$. In agreement with this hypothesis, oligomeric $A \beta$ affects LTP in the hippocampus $[5,33,43]$ and entorhinal cortex [14], two brain areas which play a fundamental role in the learning and memory process, and which are affected in AD [15]. 
Histopathological analysis of postmortem tissue has revealed that certain limbic regions, in particular hippocampus and the parahippocampal formation, are among the first affected during AD progression [15]. The visual cortex is usually considered to be relatively spared during $\mathrm{AD}$ even if all of the typical histopathological markers such as tangles, amyloid plaques, and cholinergic deficits nevertheless have been reported in this area $[22,44,45]$. Furthermore, deficits in higher order visual processing in $\mathrm{AD}$ patients have been described, including losses in color discrimination, stereoacuity, contrast sensitivity, and backward masking [17-19], suggesting a link between visual dysfunction and cognitive performance even at the early stages of AD [20-22]. These observations highlight a discrepancy between the chronological order of involvement of different brain areas and the appearance of visual dysfunction. In the present study, we hypothesized that oligomeric $A \beta$ plays an important role in the neuronal dysfunction in different brain areas, including the visual cortex. In particular, we hypothesized that at an early stage in the disease process, when levels of deposited $A \beta$ are low, cortical visual function might be impaired by $A \beta$ peptides. Indeed, the long term synaptic plasticity associated with LTP is altered by oligomeric $A \beta_{1-42}$ in the nanomolar range of concentrations $(20-200 \mathrm{nM})$. These concentrations of $A \beta$ were not sufficient to induce cell death in primary cultures of cortical neurons [14]. Thus, oligomeric $\mathrm{A} \beta_{1-42}$ disrupts the synaptic function prior to neuronal death, as shown by a reduction of LTP in the visual cortex as well as hippocampus [7] and entorhinal cortex [14].

The advantage of studying the visual cortex is that both basal synaptic transmission and long-term synaptic plasticity are well characterized in slices containing this area [40,46,47], both at the level of its cortical layers and intra-cortical connections. It is intriguing that, as we have demonstrated, the LTP elicited through stimulation of horizontal layer II/III pathway is altered by a lower concentration of $A \beta_{1-42}(20 \mathrm{nM})$ as compared with the LTP elicited through stimulation of the WM-layer II/III vertical pathway, which is affected only by a higher concentration of $\mathrm{A} \beta(200 \mathrm{nM})$. Thus synaptic disruption induced by oligomeric $A \beta$ differs within intra-cortical pathways in the occipital cortex. The present study, together with previous reports $[48,49]$ showing the presence of laminar differences within single brain areas in $\mathrm{AD}$ progress, raises the important question of whether the pattern of $\mathrm{AD}$ reflects the sensitivity of different neurons and/or synaptic connections to pathogens including $A \beta_{1-42}$. Indeed, our results indicate that the synaptic connections in the visual cortex are more vulnerable to $A \beta_{1-42}(20 \mathrm{nM})$-induced reduction of LTP compared to other brain areas, such as the hippocampus [5] and entorhinal cortex [14], in which suppression of LTP occurs at $200 \mathrm{nM}$ of $A \beta_{1-42}$. What is the functional implication of these results? It is well known that different intra-cortical connections convey specific and distinct aspects of sensory related information necessary for cognitive functions. For instance, the WM matter layer II/III vertical pathway is related to codification of sensory stimuli, while the horizontal pathway in layer II/III is more closely to elaboration and retrieval of previously stored sensory input [50]. Thus, our results suggest that during the early phase of AD characterized by low level $A \beta$, the visual function related to elaboration and retrieval of previously stored visual input is more sensitive to $A \beta$-dependent synaptic disruption. This may also help explain the early visual dysfunction observed in AD patient [17-22]. A $\beta$ has previously been linked to LTP through its effect on glutamate receptor subtypes [5,51-54]. A number of recent studies have identified RAGE as a receptor capable of binding $A \beta$ at the cell surface [23, 26], in both monomeric and oligomeric form [24,55]. RAGE immunoreactivity is present at the sites of $A \beta$ deposition increasing $A \beta$ aggregation at the cell membrane [23]. All together, these studies identify A $\beta$ signaling through RAGE as a key event for processes involved in oxidative stress, inflammation, and neurotoxicity. Furthermore, RAGE has been implicated as an important receptor mediating $A \beta$ induced neuronal and synaptic dysfunction both in hippocampus [7] and entorhinal cortex [14]. The present results are thus extended to the neocortexand show that RAGE deficiency or functional blockade of RAGE by specific antibodies counteracts the LTP dysfunction induced by oligomeric $A \beta_{1-42}$. 
These studies significantly increase the body of evidence that activation of RAGE by A $\beta$ represents a key and an early step leading to neuronal dysfunction before amyloid plaque deposition in the visual cortex.

\section{Acknowledgments}

Acknowledgment is made to the donors of the Alzheimer's Disease Research, a program of American Health Assistance Foundation (AHAF grant, A2008-335). This study was partially supported by grant from NIH (P01AG17490) to SDY, and Italian Ministero Universita' e Ricerca (PRIN, 2006) to LD. The authors gratefully acknowledge G. Cappagli and C. Orsini for their technical assistance.

Ottavio Arancio is a consultant for SMART and has received lecture fees from Acumen and Regeneron. Simona Capsoni and Antonino Cattaneo own equity shares in Lay Line Genomics. Shi Du Yan has received lecture fees from Pfizer.

\section{REFERENCES}

1. Gandy S. The role of cerebral amyloid beta accumulation in common forms of Alzheimer disease. $\mathrm{J}$ Clin Invest. 2005; 115:1121-1129. [PubMed: 15864339]

2. Stromer T, Serpell LC. Structure and morphology of the Alzheimer's amyloid fibril. Microsc Res Tech. 2005; 67:210-217. [PubMed: 16103997]

3. Walsh DM, Klyubin I, Fadeeva JV, Cullen WK, Anwyl R, Wolfe MS, Rowan MJ, Selkoe DJ. Naturally secreted oligomers of amyloid beta protein potently inhibit hippocampal long-term potentiation in vivo . Nature. 2002; 416:535-539. [PubMed: 11932745]

4. Walsh DM, Townsend M, Podlisny MB, Shankar GM, Fadeeva JV, El Agnaf O, Hartley DM, Selkoe DJ. Certain inhibitors of synthetic amyloid beta-peptide (Abeta) fibrillo-genesis block oligomerization of natural Abeta and thereby rescue long-term potentiation. J Neurosci. 2005; 25:2455-2462. [PubMed: 15758153]

5. Wang QW, Walsh DM, Rowan MJ, Selkoe DJ, Anwyl R. Block of long-term potentiation by naturally secreted and synthetic amyloid beta-peptide in hippocampal slices is mediated via activation of the kinases c-Jun N-terminal kinase, cyclin-dependent kinase 5, and p38 mitogenactivated protein kinase as well as metabotropic glutamate receptor type 5. J Neurosci. 2004; 24:3370-3378. [PubMed: 15056716]

6. Whitlock JR, Heynen AJ, Shuler MG, Bear MF. Learning induces long-term potentiation in the hippocampus. Science. 2006; 313:1093-1097. [PubMed: 16931756]

7. Arancio O, Zhang HP, Chen X, Lin C, Trinchese F, Puzzo D, Liu S, Hegde A, Yan SF, Stern A, Luddy JS, Lue LF, Walker DG, Roher A, Buttini M, Mucke L, Li W, Schmidt AM, Kindy M, Hyslop PA, Stern DM, DuYan SS. RAGE potentiates Abeta-induced perturbation of neuronal function in transgenic mice. EMBO J. 2004; 23:4096-4105. [PubMed: 15457210]

8. Hsia AY, Masliah E, McConlogue L, Yu GQ, Tatsuno G, Hu K, Kholodenko D, Malenka RC, Nicoll RA, Mucke L. Plaque-independent disruption of neural circuits in Alzheimer's disease mouse models. Proc Natl Acad Sci USA. 1999; 96:3228-3233. [PubMed: 10077666]

9. Hsiao K, Chapman P, Nilsen S, Eckman C, Harigaya Y, Younkin S, Yang F, Cole G. Correlative memory deficits, Abeta elevation, and amyloid plaques in transgenic mice. Science. 1996; 274:99102. [PubMed: 8810256]

10. Jacobsen JS, Wu CC, Redwine JM, Comery TA, Arias R, Bowlby M, Martone R, Morrison JH, Pangalos MN, Reinhart PH, Bloom FE. Early-onset behavioral and synaptic deficits in a mouse model of Alzheimer's disease. Proc Natl Acad Sci USA. 2006; 103:5161-5166. [PubMed: 16549764]

11. Redwine JM, Kosofsky B, Jacobs RE, Games D, Reilly JF, Morrison JH, Young WG, Bloom FE. Dentate gyrus volume is reduced before onset of plaque formation in PDAPP mice: a magnetic resonance microscopy and stereologic analysis. Proc Natl Acad Sci USA. 2003; 100:1381-1386. [PubMed: 12552120]

12. Reilly JF, Games D, Rydel RE, Freedman S, Schenk D, Young WG, Morrison JH, Bloom FE. Amyloid deposition in the hippocampus and entorhinal cortex: quantitative analysis of a transgenic mouse model. Proc Natl Acad Sci USA. 2003; 100:4837-4842. [PubMed: 12697936] 
13. Selkoe DJ. Alzheimer's disease is a synaptic failure. Science. 2002; 298:789-791. [PubMed: 12399581]

14. Origlia N, Righi M, Capsoni S, Cattaneo A, Fang F, Stern DM, Chen JX, Schmidt AM, Arancio O, Yan SD, Domenici L. Receptor for advanced glycation end product-dependent activation of $\mathrm{p} 38$ mitogen-activated protein kinase contributes to amyloid-beta-mediated cortical synaptic dysfunction. J Neurosci. 2008; 28:3521-3530. [PubMed: 18367618]

15. Braak H, Braak E. Demonstration of amyloid deposits and neurofibrillary changes in whole brain sections. Brain Pathol. 1991; 1:213-216. [PubMed: 1669710]

16. Metsaars WP, Hauw JJ, van Welsem ME, Duyckaerts C. A grading system of Alzheimer disease lesions in neocortical areas. Neurobiol Aging. 2003; 24:563-572. [PubMed: 12714113]

17. Cronin-Golomb A, Rizzo JF, Corkin S, Growdon JH. Visual function in Alzheimer's disease and normal aging. Ann N Y Acad Sci. 1991; 640:28-35. [PubMed: 1776752]

18. Mendez MF, Mendez MA, Martin R, Smyth KA, Whitehouse PJ. Complex visual disturbances in Alzheimer's disease. Neurology. 1990; 40:439-443. [PubMed: 2314585]

19. Rizzo M, Anderson SW, Dawson J, Nawrot M. Vision and cognition in Alzheimer's disease. Neuropsychologia. 2000; 38:1157-1169. [PubMed: 10838150]

20. Becker JT, Huff FJ, Nebes RD, Holland A, Boller F. Neuropsychological function in Alzheimer's disease. Pattern of impairment and rates of progression. Arch Neurol. 1988; 45:263-268. [PubMed: 3341951]

21. Flicker C, Ferris SH, Reisberg B. Mild cognitive impairment in the elderly: predictors of dementia. Neurology. 1991; 41:1006-1009. [PubMed: 2067629]

22. Ikonomovic MD, Mufson EJ, Wuu J, Bennett DA, DeKosky ST. Reduction of choline acetyltransferase activity in primary visual cortex in mild to moderate Alzheimer's disease. Arch Neurol. 2005; 62:425-430. [PubMed: 15767507]

23. Yan SD, Chen X, Fu J, Chen M, Zhu H, Roher A, Slattery T, Zhao L, Nagashima M, Morser J, Migheli A, Nawroth P, Stern D, Schmidt AM. RAGE and amyloid-beta peptide neurotoxicity in Alzheimer's disease. Nature. 1996; 382:685-691. [PubMed: 8751438]

24. Chen X, Walker DG, Schmidt AM, Arancio O, Lue LF, Yan SD. RAGE: a potential target for Abeta-mediated cellular perturbation in Alzheimer's disease. Curr Mol Med. 2007; 7:735-742. [PubMed: 18331231]

25. Deane R, Yan SD, Submamaryan RK, LaRue B, Jovanovic S, Hogg E, Welch D, Manness L, Lin C, Yu J, Zhu H, Ghiso J, Frangione B, Stern A, Schmidt AM, Armstrong DL, Arnold B, Liliensiek B, Nawroth P, Hofman F, Kindy M, Stern D, Zlokovic B. RAGE mediates amyloid-beta peptide transport across the blood-brain barrier and accumulation in brain. Nat Med. 2003; 9:907-913. [PubMed: 12808450]

26. Lue LF, Walker DG, Brachova L, Beach TG, Rogers J, Schmidt AM, Stern DM, Du Yan S. Involvement of microglial receptor for advanced glycation endproducts (RAGE) in Alzheimer's disease: Identification of a cellular activation mechanism. Exp Neurol. 2001; 171:29-45. [PubMed: 11520119]

27. Yan SD, Yan SF, Chen X, Fu J, Chen M, Kuppusamy P, Smith MA, Perry G, Godman GC, Nawroth $\mathrm{P}$, et al. Non-enzymatically glycated tau in Alzheimer's disease induces neuronal oxidant stress resulting in cytokine gene expression and release of amyloid beta-peptide. Nat Med. 1995; 1:693-699. [PubMed: 7585153]

28. Lue LF, Yan SD, Stern DM, Walker DG. Preventing activation of receptor for advanced glycation endproducts in Alzheimer's disease. Curr Drug Targets CNS Neurol Disord. 2005; 4:249-266. [PubMed: 15975028]

29. Schmidt AM, Yan SD, Yan SF, Stern DM. The multiligand receptor RAGE as a progression factor amplifying immune and inflammatory responses. J Clin Invest. 2001; 108:949-955. [PubMed: 11581294]

30. Hofmann MA, Drury S, Fu CF, Qu W, Taguchi A, Lu Y, Avila C, Kambham N, Bierhaus A, Nawroth P, Neurath MF, Slattery T, Beach D, McClary J, Nagashima M, Morser J, Stern D, Schmidt AM. RAGE mediates a novel proinflammatory axis: A central cell surface receptor for S100/calgranulin polypeptides. Cell. 1999; 97:889-901. [PubMed: 10399917] 
31. Sakaguchi T, Yan SF, Yan SD, Belov D, Rong LL, Sousa M, Andrassy M, Marso SP, Duda S, Arnold B, Liliensiek B, Nawroth PP, Stern DM, Schmidt AM, Naka Y. Central role of RAGEdependent neointimal expansion in arterial restenosis. J Clin Invest. 2003; 111:959-972. [PubMed: 12671045]

32. Wendt TM, Tanji N, Guo JC, Kislinger TR, Qu W, Lu Y, Bucciarelli LG, Rong LL, Moser B, Markowitz GS, Stein G, Bierhaus A, Liliensiek B, Arnold B, Nawroth PP, Stern DM, D’Agati VD, Schmidt AM. RAGE drives the development of glomerulosclerosis and implicates podocyte activation in the pathogenesis of diabetic nephropathy. Am J Pathol. 2003; 162:1123-1137. [PubMed: 12651605]

33. Puzzo D, Vitolo O, Trinchese F, Jacob JP, Palmeri A, Arancio O. Amyloid-beta peptide inhibits activation of the nitric oxide/cGMP/cAMP-responsive element-binding protein pathway during hippocampal synaptic plasticity. J Neurosci. 2005; 25:6887-6897. [PubMed: 16033898]

34. Trinchese F, Fa M, Liu S, Zhang H, Hidalgo A, Schmidt SD, Yamaguchi H, Yoshii N, Mathews PM, Nixon RA, Arancio O. Inhibition of calpains improves memory and synaptic transmission in a mouse model of Alzheimer disease. J Clin Invest. 2008; 118:2796-2807. [PubMed: 18596919]

35. Haass C, Selkoe DJ. Soluble protein oligomers in neurodegeneration: lessons from the Alzheimer's amyloid beta-peptide. Nat Rev Mol Cell Biol. 2007; 8:101-112. [PubMed: 17245412]

36. Cadene M, Chait BT. A robust, detergent-friendly method for mass spectrometric analysis of integral membrane proteins. Anal Chem. 2000; 72:5655-5658. [PubMed: 11101244]

37. Domenici L, Harding GW, Burkhalter A. Patterns of synaptic activity in forward and feedback pathways within rat visual cortex. J Neurophysiol. 1995; 74:2649-2664. [PubMed: 8747222]

38. Pesavento E, Capsoni S, Domenici L, Cattaneo A. Acute cholinergic rescue of synaptic plasticity in the neurodegener-ating cortex of anti-nerve-growth-factor mice. Eur J Neurosci. 2002; 15:1030-1036. [PubMed: 11918663]

39. Anderson WW, Collingridge GL. The LTP Program: a data acquisition program for on-line analysis of long-term potentiation and other synaptic events. J Neurosci Meth. 2001; 108:71-83.

40. Origlia N, Capsoni S, Domenici L, Cattaneo A. Time window in cholinomimetic ability to rescue long-term potentiation in neurodegenerating anti-nerve growth factor mice. J Alzheimers Dis. 2006; 9:59-68. [PubMed: 16627935]

41. Cleary JP, Walsh DM, Hofmeister JJ, Shankar GM, Kuskowski MA, Selkoe DJ, Ashe KH. Natural oligomers of the amyloid-protein specifically disrupt cognitive function. Nat Neurosci. 2005; 8:79-84. [PubMed: 15608634]

42. Lesne S, Koh MT, Kotilinek L, Kayed R, Glabe CG, Yang A, Gallagher M, Ashe KH. A specific amyloid-beta protein assembly in the brain impairs memory. Nature. 2006; 440:352-357. [PubMed: 16541076]

43. Vitolo OV, Sant'Angelo A, Costanzo V, Battaglia F, Arancio O, Shelanski M. Amyloid betapeptide inhibition of the PKA/CREB pathway and long-term potentiation: Reversibility by drugs that enhance cAMP signaling. Proc Natl Acad Sci USA. 2002; 99:13217-13221. [PubMed: 12244210]

44. Davis KL, Mohs RC, Marin D, Purohit DP, Perl DP, Lantz M, Austin G, Haroutunian V. Cholinergic markers in elderly patients with early signs of Alzheimer disease. JAMA. 1999; 281:1401-1406. [PubMed: 10217056]

45. Morrison JH, Hof PR, Bouras C. An anatomic substrate for visual disconnection in Alzheimer's disease. Ann N Y Acad Sci. 1991; 640:36-43. [PubMed: 1776757]

46. Kirkwood A, Bear MF. Homosynaptic Long-Term Depression in the Visual-Cortex. J Neurosci. 1994; 14:3404-3412. [PubMed: 8182481]

47. Kirkwood A, Lee HK, Bear MF. Coregulation of long-term potentiation and experience-dependent synaptic plasticity in visual-cortex by age and experience. Nature. 1995; 375:328-331. [PubMed: 7753198]

48. Hyman BT, Van Hoesen GW, Damasio AR, Barnes CL. Alzheimer's disease: cell-specific pathology isolates the hippocampal formation. Science. 1984; 225:1168-1170. [PubMed: 6474172] 
49. Gómez-Isla T, Price JL, McKeel DWJ, Morris JC, Growdon JH, Hyman BT. Profound loss of layer II entorhinal cortex neurons occurs in very mild Alzheimer's disease. J Neurosci. 1996; 16:491-500.

50. Hasselmo ME, Giocomo LM. Cholinergic modulation of cortical function. J Mol Neurosci. 2006; 30:133-135. [PubMed: 17192659]

51. Parameshwaran K, Sims C, Kanju P, Vaithianathan T, Shonesy BC, Dhanasekaran M, Bahr BA, Suppiramaniam V. Amyloid beta-peptide Abeta(1-42) but not Abeta (1-40) attenuates synaptic AMPA receptor function. Synapse. 2007; 61:367-374. [PubMed: 17372971]

52. Shemer I, Holmgren C, Min R, Fulop L, Zilberter M, Sousa KM, Farkas T, Hartig W, Penke B, Burnashev N, Tanila H, Zilberter Y, Harkany T. Non-fibrillar beta-amyloid abates spike-timingdependent synaptic potentiation at excitatory synapses in layer $2 / 3$ of the neocortex by targeting post-synaptic AMPA receptors. Eur J Neurosci. 2006; 23:2035-2047. [PubMed: 16630051]

53. Shemer I, Holmgren C, Min R, Fulop L, Zilberter M, Sousa KM, Farkas T, Hartig W, Penke B, Burnashev N, Tanila H, Zilberter Y, Harkany T. Non-fibrillar beta-amyloid abates spike-timingdependent synaptic potentiation at excitatory synapses in layer $2 / 3$ of the neocortex by targeting post-synaptic AMPA receptors. Eur J Neurosci. 2006; 23:2035-2047. [PubMed: 16630051]

54. Zhao D, Watson JB, Xie CW. Amyloid beta prevents activation of calcium/calmodulin-dependent protein kinase II and AMPA receptor phosphorylation during hippocampal long-term potentiation. J Neurophysiol. 2004; 92:2853-2858. [PubMed: 15212428]

55. Ding QX, Keller JN. Evaluation of rage isoforms, ligands, and signaling in the brain. Biochim Biophys Acta. 2005; 1746:18-27. [PubMed: 16214242] 

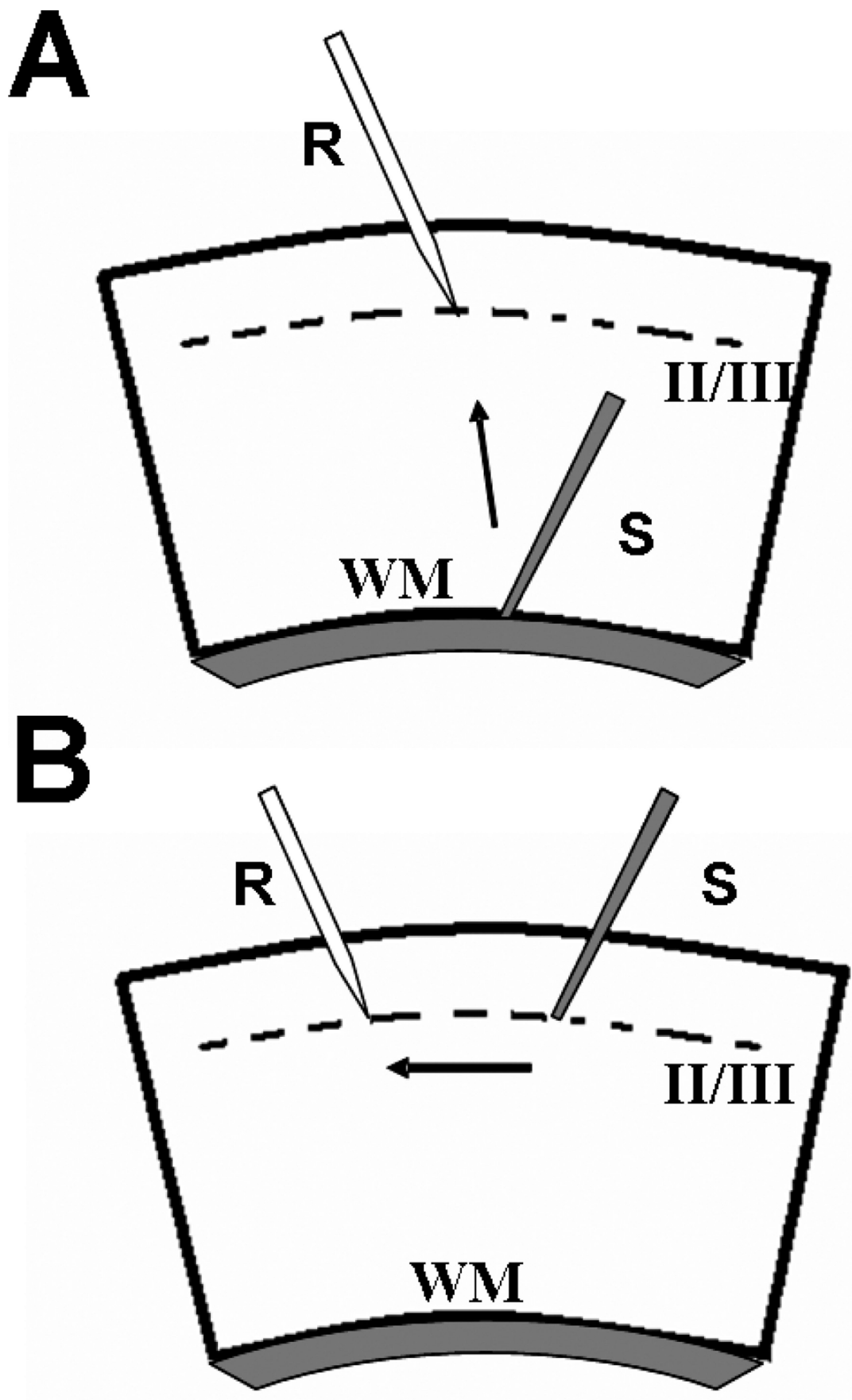

Fig. 1.

Schematic drawing of cortical slices and position of electrodes. (A) Representation of vertical WM-layer II/III pathway; the stimulating electrode(s) is placed at WM/layer VI boarder while the recording pipette (r) is positioned in layer II/III (corresponding to $300 \mu \mathrm{M}$ below pial surface). (B) For stimulation of intracortical horizontal pathway, recording- (r) and stimulating- (s) electrodes were placed within the same layer (II/III). 


\section{Mass spectrometry of $A \beta_{1-42}$ oligomeric solution}

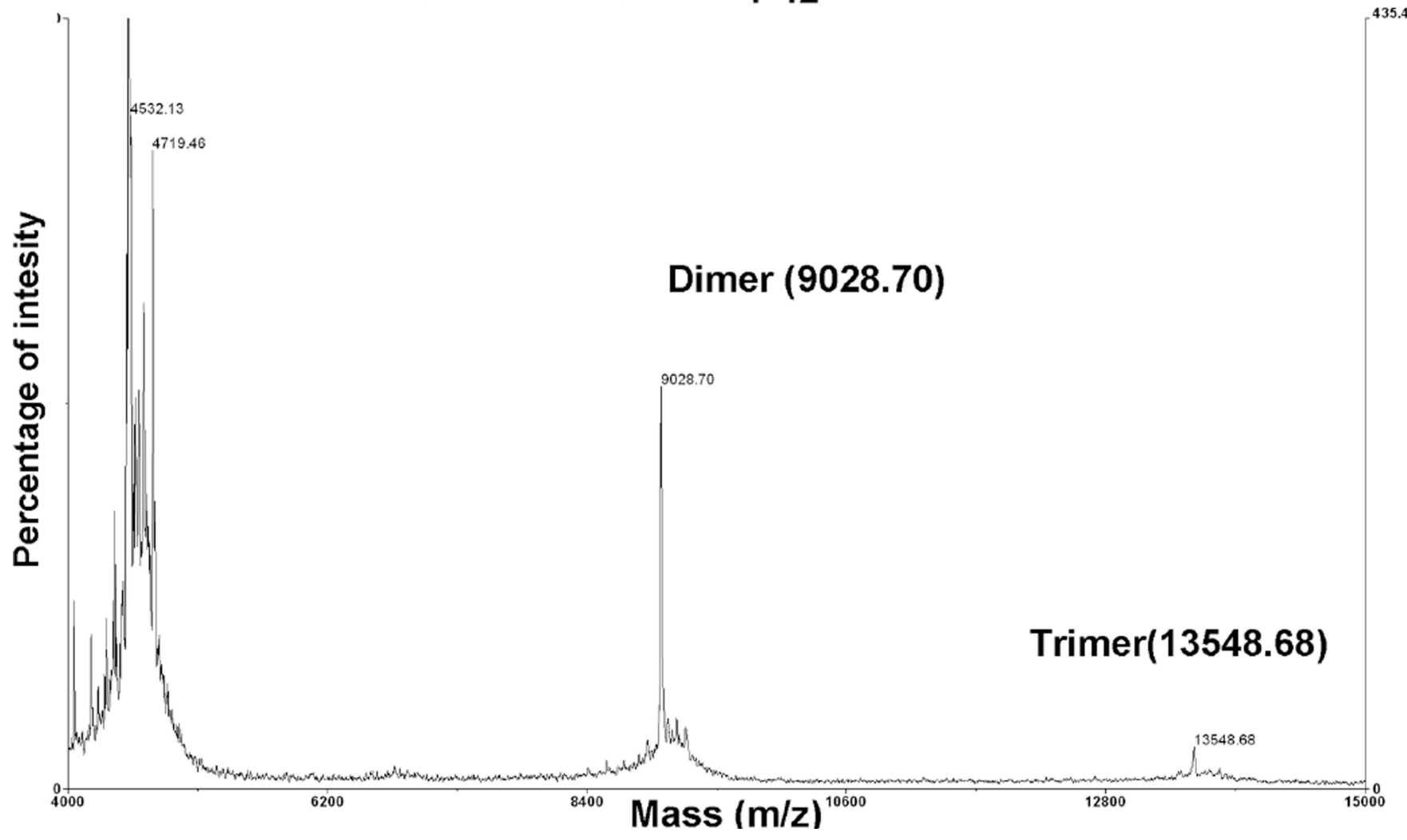

Fig. 2.

Mass spectrometry analysis of $A \beta_{1-42}$. Oligomeric composition of $A \beta_{1-42}$ preparation was characterized by using mass spectrometry. Spectra were acquired on a Voyager-DE Pro (Applied Biosystems, Foster City, CA) as described in Materials and Methods. The main signals corresponded to the molecular ions of $\mathrm{A} \beta$ monomers, dimers, and trimers. 

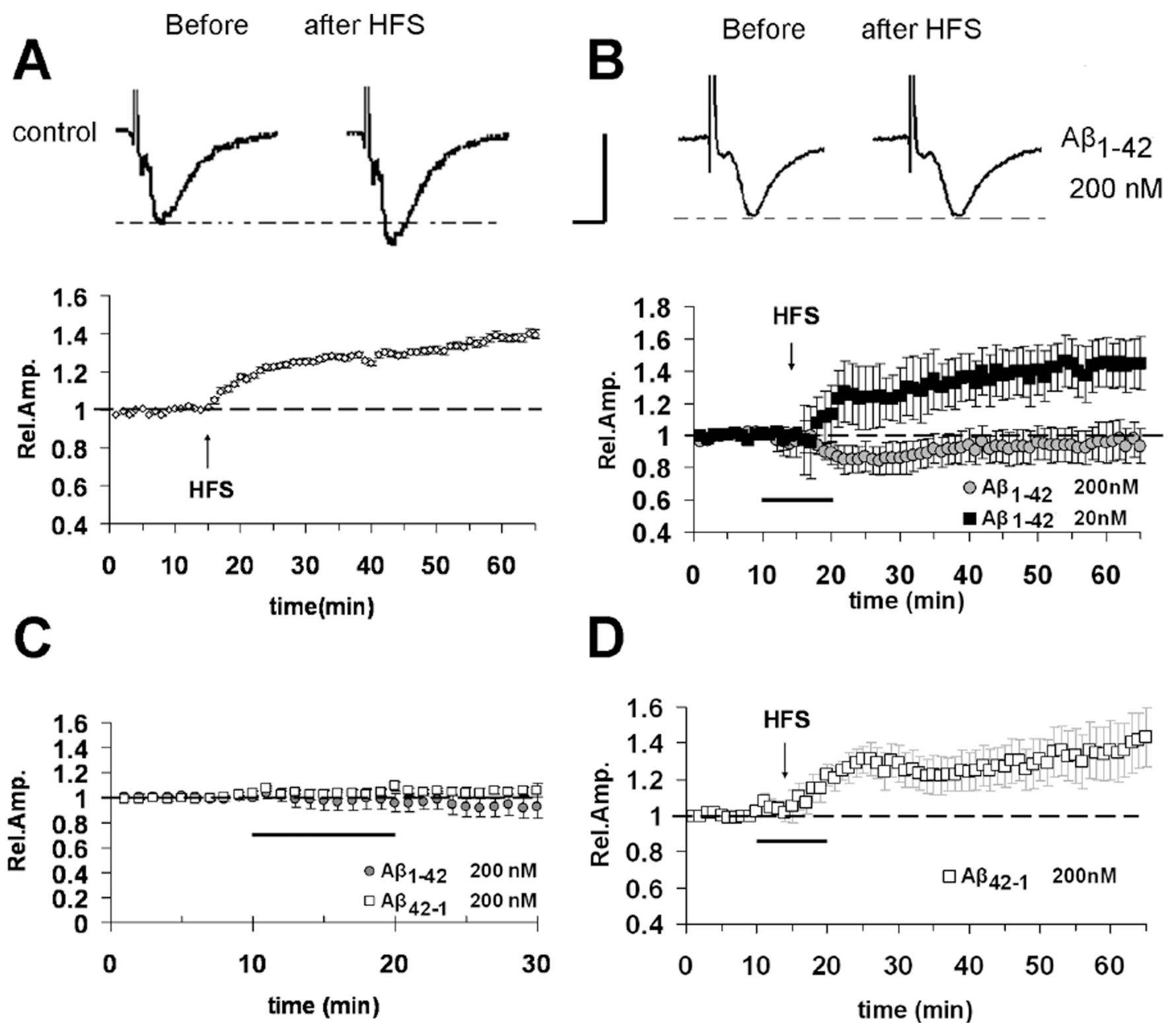

D

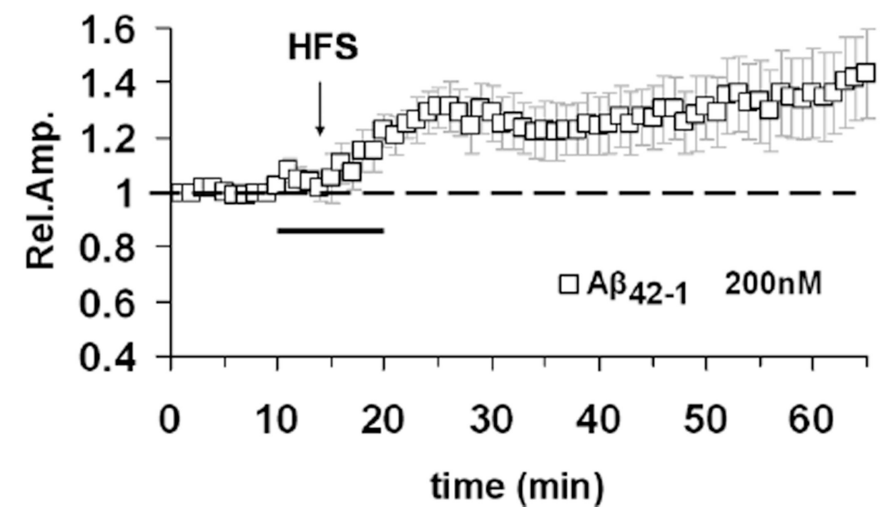

Fig. 3.

Inhibitory effect of $A \beta_{1-42}$ on LTP elicited by the stimulation of vertical WM-Layer II/III pathway in cortical slices. (A) Under control conditions, LTP expression is induced by HFS of WM, applied after 15 minutes of baseline recording. (B) LTP is inhibited by A $\beta_{1-42} 200$ $\mathrm{nM}$ (bath applied for 10 minutes starting from 5 minutes before HFS, dark bar; gray circles) while no effect is observed for a lower concentration of $A \beta(20 \mathrm{nM}$, filled squares).(C) No effect on basal synaptic transmission was observed in the presence of $A \beta_{1-42}(200 \mathrm{nM})$ or the reverse control peptide $A \beta_{42-1}(200 \mathrm{nM})$ (dark bar represents application time of $A \beta$ peptides). (D) No effect on LTP expression was observed in the presence of the control reverse peptide $A \beta_{42-1}(200 \mathrm{nM})$. The top inserts of panels $A-B$ show representative field potentials recorded before and 50 minutes after HFS (vertical scale bar $=0.5 \mathrm{mV}$; horizontal scale bar $=5 \mathrm{~ms}$ ). 

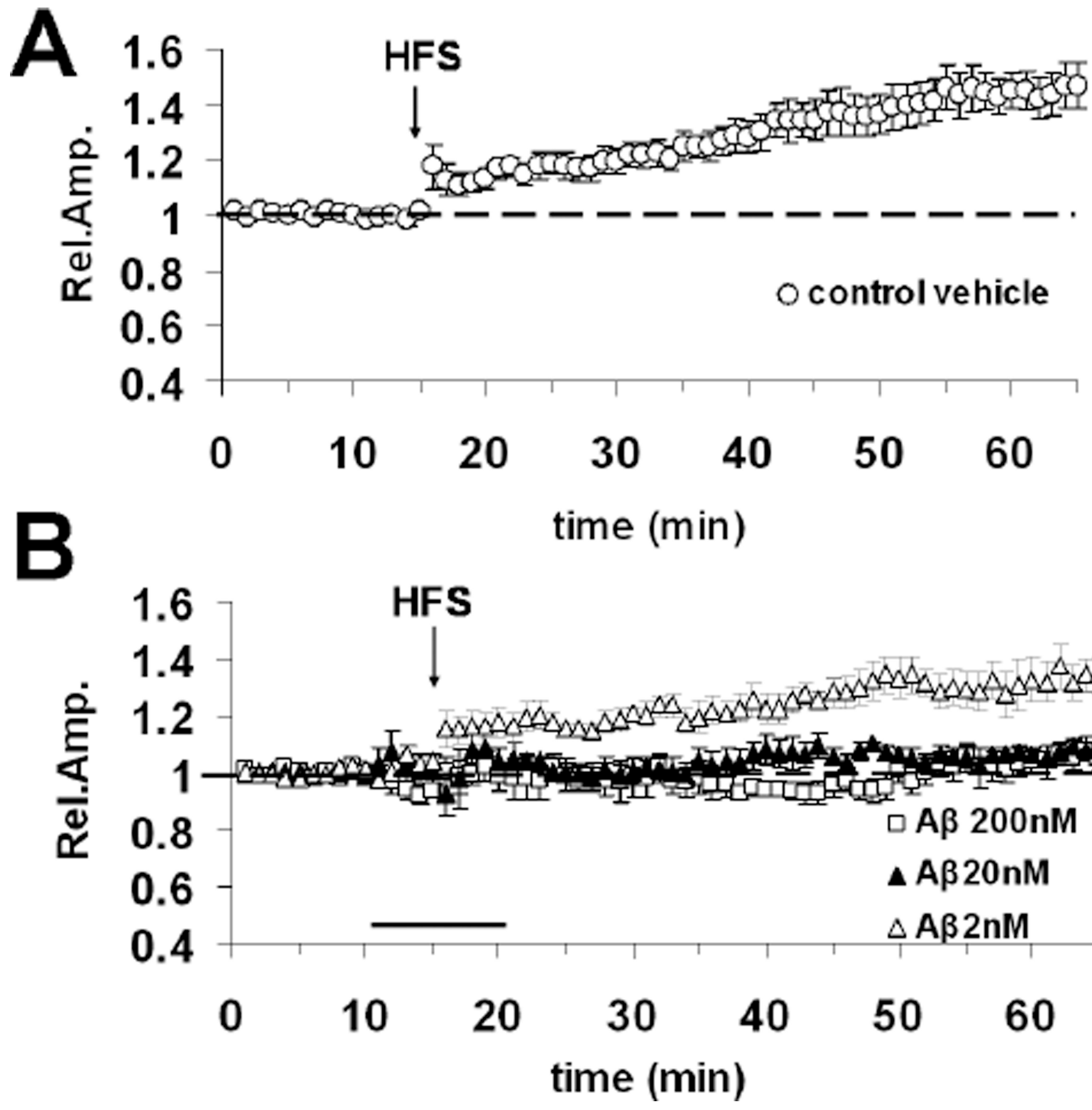

Fig. 4.

$\mathrm{A} \beta_{1-42}$ inhibits LTP elicited by the stimulation of the horizontal layer II/III ortical pathway.

(A) LTP expression invehicle treated slices after HFS of layer II/III (horizontal pathway).

(B) Effect of 10 minute bath application (horizontal dark bar) of different $A \beta_{1-42}$

concentrations $(2,20$ and $200 \mathrm{nM})$ on horizontal pathway LTP expression. 

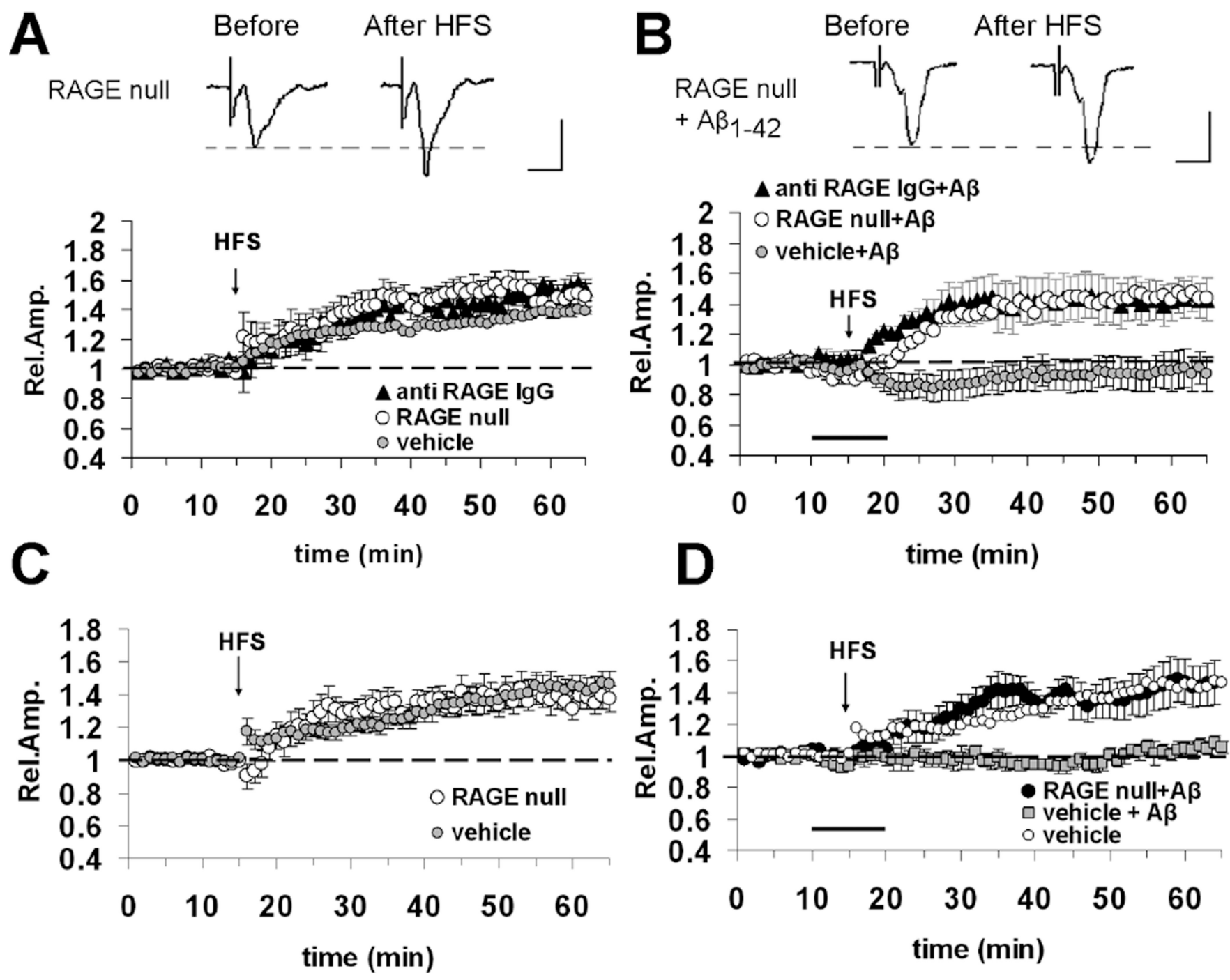

Fig. 5.

Blockade of RAGE protects against $A \beta_{1-42}(200 \mathrm{nM})$-induced impairment of cortical LTP. (A) LTP elicited by HFS of WM-Layer II/III pathway is unaffected in slices from RAGE null mice (open circles) or in slices pre-incubated with anti-RAGE $\operatorname{IgG}(2.5 \mu \mathrm{g} / \mathrm{ml}$ for 2 hours, filled triangles). (B) Bath application (dark bar) of $A \beta_{42-1}(200 \mathrm{nM})$ is unable to inhibit LTP elicited by HFS of WM-Layer II/III pathway in slices from RAGE null mice (open circles) or in slices pre-incubated with anti RAGE IgG $(2.5 \mu \mathrm{g} / \mathrm{ml}$ for 2 hours, filled triangles). In (A) and (B) top inserts show representative field potentials recorded before and 50 minutes after HFS (vertical scale bar $=0.5 \mathrm{mV}$; horiz. scale bar $=5 \mathrm{~ms}$ ). (C) LTP elicited by HFS of horizontal layer II/III pathway is not altered in cortical slices from RAGE null mice. (D) RAGE deficiency (RAGE null slices) rescues normal LTP elicited by HFS of horizontal layer II/III pathway in A $\beta$-treated cortical slices (dark bar). 